\title{
Review \\ Sudden Death in Adults: A Practical Flow Chart for Pathologist Guidance
}

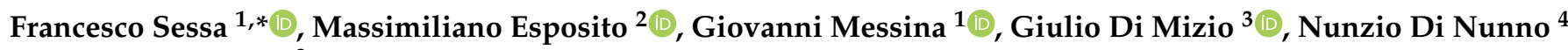 \\ and Monica Salerno ${ }^{2}$ \\ 1 Department of Clinical and Experimental Medicine, University of Foggia, 71122 Foggia, Italy; \\ giovanni.messina@unifg.it \\ 2 Department of Medical, Surgical and Advanced Technologies "G.F. Ingrassia", University of Catania, \\ 95121 Catania, Italy; massimiliano.esposito91@gmail.com (M.E.); monica.salerno@unict.it (M.S.) \\ 3 Forensic Medicine, Department of Law, Economy and Sociology, Campus "S. Venuta", Magna Graecia \\ University, 88100 Catanzaro, Italy; giulio.dimizio@unicz.it \\ 4 Department of History, Society and Studies on Humanity, University of Salento, 73100 Lecce, Italy; \\ nunzio.dinunno@icloud.com \\ * Correspondence: francesco.sessa@unifg.it; Tel.: +39-0881-7369-26 or +39-349-395-0396
}

Citation: Sessa, F.; Esposito, M.; Messina, G.; Di Mizio, G.; Di Nunno, N.; Salerno, M. Sudden Death in Adults: A Practical Flow Chart for Pathologist Guidance. Healthcare 2021, 9, 870. https://doi.org/10.3390/ healthcare 9070870

Academic Editor: Mariano Cingolani

Received: 9 June 2021

Accepted: 8 July 2021

Published: 9 July 2021

Publisher's Note: MDPI stays neutral with regard to jurisdictional claims in published maps and institutional affiliations.

Copyright: (c) 2021 by the authors. Licensee MDPI, Basel, Switzerland. This article is an open access article distributed under the terms and conditions of the Creative Commons Attribution (CC BY) license (https:// creativecommons.org/licenses/by/ $4.0 /)$.

\begin{abstract}
The medico-legal term "sudden death (SD)" refers to those deaths that are not preceded by significant symptoms. SD in apparently healthy individuals (newborn through to adults) represents a challenge for medical examiners, law enforcement officers, and society as a whole. This review aims to introduce a useful flowchart that should be applied in all cases of SD. Particularly, this flowchart mixes the data obtained through an up-to-date literature review and a revision of the latest version of guidelines for autopsy investigation of sudden cardiac death (SCD) in order to support medico-legal investigation. In light of this review, following the suggested flowchart step-by-step, the forensic pathologist will be able to apply all the indications of the scientific community to real cases. Moreover, it will be possible to answer all questions relative to $\mathrm{SD}$, such as: death may be attributable to cardiac disease or to other causes, the nature of the cardiac disease (defining whether the mechanism was arrhythmic or mechanical), whether the condition causing SD may be inherited (with subsequent genetic counseling), the assumption of toxic or illicit drugs, traumas, and other unnatural causes.
\end{abstract}

Keywords: sudden death (SD); sudden cardiac death (SCD); autopsy; molecular autopsy; genetics; post-mortem investigation; practical flowchart in SD

\section{Introduction}

The medico-legal term "sudden death (SD)" (also called "sudden and unexpected natural death") refers to those deaths that are not preceded by significant symptoms. The term thus used obviously excludes violent or traumatic deaths. There is no universally accepted definition of sudden death, and time periods ranging from 1 to $48 \mathrm{~h}$ have been used in several countries. For example, the World Health Organization (WHO) definition of SD is a "death occurring within $24 \mathrm{~h}$ after the onset of the symptoms" [1]; while the Association for European Cardiovascular Pathology has defined SD as "a natural death that occurs within $6 \mathrm{~h}$ of the beginning of symptoms in an apparently healthy subject or in one whose disease is not so severe that a fatal outcome would be expected" [2].

$\mathrm{SD}$ in apparently healthy individuals (from newborn through to adults) represents a very challenging event for medical examiners, law enforcement officers, and society as a whole [3]. It is particularly difficult to interpret epidemiological data, considering the lack of standardization in death certificate coding and the variability in the definition of SD. Some causes of SD are identifiable through collecting several important pieces of evidence during the external examination, crime scene investigation, and autopsy [4-6]. Moreover, anamnesis and clinical data should be collected in order to identify the exact cause of 
death $[7,8]$. Nevertheless, in many cases of SD that present to the medical examiner or coroner, all collected data do not reveal the cause of death [9].

Several SDs are not necessarily "unexpected", and some unexpected deaths are not necessarily "sudden": for this reason, it is extremely important that these autopsies be carried out, and that they are conducted properly. Notably, autopsy findings may have profound effects on the lives and welfare of the family of the deceased, law enforcement agencies, hospital authorities, and private corporations, including insurance companies [10].

In this scenario, this narrative review introduces a useful flowchart that should be applied in all cases of SD. In particular, this flowchart was obtained combining the data obtained through an up-to-date literature review and a revision of the latest version of guidelines for autopsy investigation of sudden cardiac death (SCD) [11] in order to support medico-legal investigations. The choice of the articles for this narrative review was made after evaluation by the authors following a screening of abstracts in the PUBMED database, using the following search terms: "Causes of SD", "SD and Cardiovascular system", "SD and Respiratory System", "SD and Central Nervous System", "SD and Abdominal causes", "SD and Endocrine System", "SD and Iatrogenic", and "SD and Miscellaneous".

\section{Causes of Sudden Death}

The most prevalent cause of death in the case of SD is related to cardiovascular diseases; nevertheless, when a subject suddenly dies, and the pathologist after the postmortem examination is not able to identify abnormalities of the cardiac anatomy, a variety of conduction abnormalities without morphological evidence visible at autopsy may be suspected. In light of these considerations, other organs may be involved: these cases of SDs are usually defined as non-cardiac sudden death (nc-SD).

Based on these considerations, SD may be classified under the criteria of the anatomical system involved. It is clear that following these criteria, some degree of overlapping is inevitable. In Figure 1, a system of classification of SD is proposed.

\section{Central Nervous System}

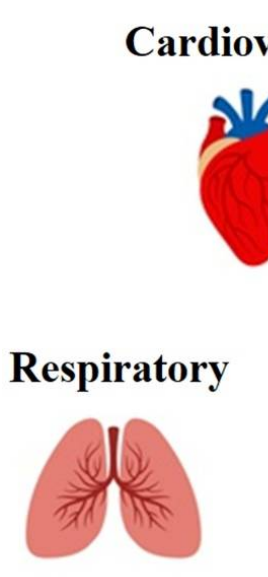

Abdominal

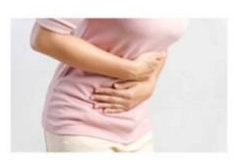

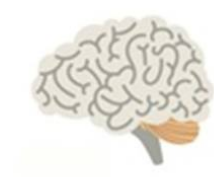

Endocrine
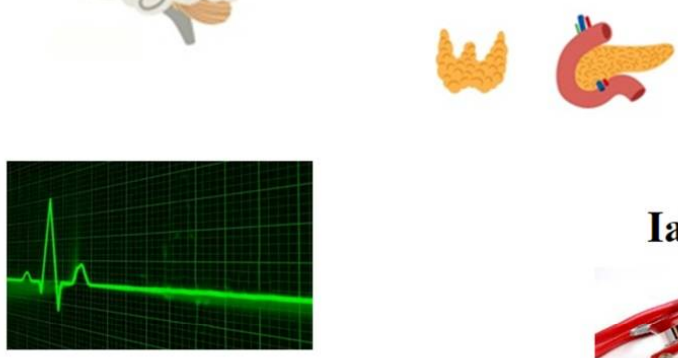

Sudden Death

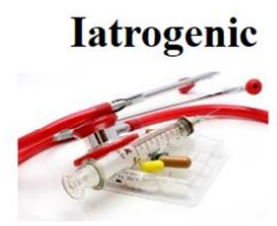

Miscellaneous

\section{Indeterminate}
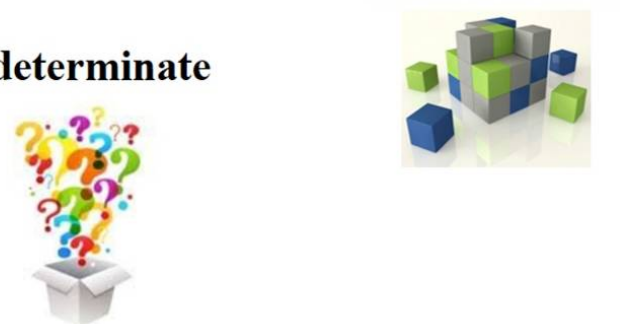

Figure 1. A classification of the possible cause of death in cases of SD. 


\subsection{Cardiovascular System}

The first cause of SD worldwide is cardiovascular diseases, accounting for approximately $90 \%$ of such cases [9]. These data are referred to developed countries such as the USA, Japan, and various European countries. When the cardiovascular system is involved, SCD is used. The definitions of SCD are not the same across the scientific community [12]. The incidence of SCD increases with age, varying from about 1 per 1000 per year in subjects of 35-40 years, 2 per 1000 per year by 60 years, and 200 per 1000 per year in the elderly $[13,14]$. The use of post-mortem imaging is very important in the classification of SCD. Based on these criteria, they may be divided into coronary and non-coronary causes:

- coronary artery diseases (CAD) represent the majority of cardiovascular deaths, even if the data about the percentage are various, ranging from $56.87 \%$ [15] to $80 \%$ [9]. The percentage of CAD deaths is closely related to age: indeed, it was highest in subjects over 40 years old. CAD may be further divided into atherosclerotic and nonatherosclerotic types. In this subdivision, the atherosclerotic type accounts for most cases, while non-atherosclerotic coronary artery diseases are included in congenital abnormalities, embolism, arteritis, dissecting aneurysms, and external compression or ostial obstruction;

- non-coronary cardiovascular diseases are strictly related to congenital anomalies, valvular heart diseases such as rheumatic heart disease and syphilis, hypertensive heart disease, myocarditis, ruptured aortic aneurysm (acute aortic dissection), and cardiomyopathy [16]. In a simplistic classification, SD due to cardiac genetic alterations could be subdivided into two main groups, channelopathies, and cardiomyopathies $[17,18]$.

The so-called SCDs in the majority of cases are due to coronary artery disease. The post-mortem findings both at the gross examination and at the histological investigations frequently support this kind of diagnosis, describing a clinical picture of severe coronary artery atherosclerosis. They may be associated with coronary artery thrombosis, recent myocardial infarction, and myocardial fibrosis subsequent to different events such as infarction. Nevertheless, these findings are variable and relatively infrequent: for these reasons, they may not be considered decisive to validate the diagnosis [19].

The autopsy finding of critical coronary stenosis (defined as one or more of the major extramural coronary arteries with more than $75 \%$ narrowing of the luminal cross-section) is sufficient to invoke a diagnosis of SCD, and this is consistently detected in $90 \%$ or more of these patients. Death is believed to be due to rhythm disorders, i.e., dysrhythmias, in most of these cases. In the adult, it is estimated that 10 to $25 \%$ of SCD could be related to cardiac channelopathies [20].

Several risk factors for SCD have been reported [21], with age and sex representing two important factors: indeed, the risk of SD is greater in males and obviously increases with age. The death rate improves significantly in middle-old age, especially from age 45 to 64 years [22]. Another important factor is the presence of previous coronary artery disease [23]. Patients with known coronary artery disease had a fourfold greater incidence of SD. Nevertheless, about $55 \%$ of those dying suddenly had manifested no prior evidence of coronary artery disease. Another important heart disease closely related to SCD is left ventricular hypertrophy: as previously described, patients with ECG evidence of left ventricular hypertrophy had a 5-fold increased incidence of SD.

In this scenario, hypertension and blood cholesterol may be considered two important indirect risk factors in the insurgence of SCD events. Notably, men with systolic blood pressures $>160 \mathrm{~mm} \mathrm{Hg}$ have an incidence of SD three times greater than those who have systolic pressures $<140 \mathrm{~mm} \mathrm{Hg}$; moreover, elevated cholesterol levels are generally regarded as a risk factor, even if, to date, no stepwise trend proportional to serum cholesterol has been noted [24]. Obviously, overweight and obese status is related to SCD. It has been described that the risk of this tragic event increases progressively with increased weight, arriving at more than doubled for those weighing $120 \%$ or more than their ideal weight [25]. Other important indirect factors that could be considered are cigarette smoking and alcohol/drug 
abuse. In particular, smokers had a 3-fold greater incidence of SD than non-smokers; moreover, the abuser (meaning smokers of $>1$ pack per day) had higher rates than did smokers of $<1$ pack per day [26].

In this context, an infrequent but always tragic event occurs when SD happens in an apparently healthy young adult from spontaneous causes. Although the causes of SD in young subjects are scarce, the most prevalent cause of death is related to cardiovascular disease, with primary arrhythmogenic disorders, atherosclerotic events, cardiomyopathies, and myocarditis as the main contributors. Indeed, in a recent article by Vos et al. [27], cardiovascular diseases and genetic arrhythmias accounted for about $50 \%$ of their SD cases. Indeed, based on international data, it is estimated that up to one-third of infantile and juvenile SCD may be explained by cardiac channelopathies [28-31]. The most frequent channelopathies include the long QT syndrome (LQTS), short QT syndrome (SQTS), catecholaminergic polymorphic ventricular tachycardia (CPVT), and Brugada syndrome (BrS) [32-34]. Moreover, in the case of SCD in young people, it could be possible to detect pathogenic mutations in genes encoding structural proteins. These mutations could determine several diseases such as hypertrophic cardiomyopathy, dilated cardiomyopathy, and arrhythmogenic cardiomyopathy (AC) [35]. The majority of these cardiomyopathies may be diagnosed at autopsy, considering that usually, anatomo-morphological changes in cardiac tissue are detected, especially in young adults [36]. Indeed, as recently described, a primary myocardial fibrosis at autopsy is strictly related to variants in genes associated with arrhythmogenic right ventricular cardiomyopathy, dilated cardiomyopathy, and hypertrophic cardiomyopathy; when autopsy does not show these findings, primary myocardial fibrosis may represent an alternative phenotypic expression of structural disease-associated genetic variants, or that risk-associated fibrosis was expressing before the primary disease [37]. Contrariwise, when this tragic event occurs in an infant, a structurally normal heart is usually reported in the post-mortem documentation [38].

One of the most difficult problems for forensic pathologists is the diagnose of SD in subjects with acute cardiac processes that progress rapidly, with non-specific symptoms, leading to death without evident morphological alterations. In these cases, innovative approaches are frequently proposed. For example, post-mortem magnetic resonance imaging could be one of the most promising tools to identify cardiac pathological alterations, highlighting evidence otherwise not visible with routine autopsy [39]. In the same way, the use of biochemical markers in cadaver fluids is frequently investigated as complementary indicators to help to reach valid conclusions about the cause of death. Although the ideal sampling site is debatable, several studies propose either pericardial fluid or peripheral veins as the location for the biological sample. A recent article suggests that cardiac troponin I (cTnI) values in pericardial fluid and the troponin ratio (pericardial fluid/serum ratio) may be helpful in SCD [40]. Finally, immunohistochemical investigation combined with western blot analysis is used to detect morphological changes in myocardial specimens of fatal SD, quantifying the effects of cardiac expression of inflammatory mediators (CD15, IL-1 $\beta$, IL-6, TNF- $\alpha$, IL-15, IL-8, MCP-1, ICAM-1, CD18, tryptase) and structural and functional cardiac proteins (troponin I and troponin C) [41].

When SD occurs in a young subject, it may occur during sports activities. In large postmortem investigations studies of athlete populations in the United States, hypertrophic cardiomyopathy was the most common cardiovascular cause of SD [42]. The second most frequent cardiovascular cause of SD in the subjects practicing sports activities is congenital coronary-artery anomalies: in these cases, the artery originates from the wrong aortic sinus (more commonly, the left main coronary artery originates from Valsalva's right sinus) [43]. Other causes of death are congenital cardiac malformations, such as congenital valvular disease, aortic stenosis, myxomatous mitral valve degeneration (typically associated with Marfan's syndrome), as well as other causes such as myocarditis and coronary atherosclerotic disease [44-46].

A molecular autopsy should be considered fundamental in the case of SD in young people, seeking to always incorporate genetic testing into the post-mortem examination. 
Moreover, it has been proposed that community-based data aggregation and sharing should be mandatory, leading to an improved classification of genetic variants [47,48].

\subsection{Respiratory System}

The most important cause of death in the case of nc-SD involving the respiratory system is acute pulmonary embolism (APE). The symptoms of APE are various with a complex clinical picture. Indeed, APE is characterized by numerous clinical manifestations with a complex interaction between different organs. In this scenario, it is very difficult to make an immediate diagnosis [49].

Fatal pulmonary embolism (PE) represents the common cause of SD related to the respiratory system, usually resulting from a complication of deep venous thrombosis (DVT). Typical symptom and signs of $\mathrm{PE}$ is angina with pleuritic chest pain as a consequence of pleural involvement due to pulmonary infarction [50,51]. In fulminant PE, up to $90 \%$ of cardiac arrests occur within 1 to $2 \mathrm{~h}$ after the onset of symptoms [52]. The mortality rate related to PE is high and it is due to the principal causes: pulmonary mainstream obstruction and liberation of vasoconstrictive mediators from the thrombi [53]. For example, pulmonary thromboembolism has been identified as one of the common clinical pictures of COVID-19, justifying SD in several subjects who died from SARS-CoV-2 infection [54-56]. Other clinical pictures of APE are: symptoms similar to acute respiratory distress syndrome (ARDS) [57]; fever syndrome with or without pseudopneumonia [58]; acute right heart failure/shock/hypotension (often with epigastric pain) [59]; left heart failure (with pulmonary congestion) [60]; chest pain similar to pleuritic syndrome with or without hemoptysis (with or without effusion) [61]; similar to acute coronary syndrome (ACS) (with or without chest pain) [62]; syncope [63]; complete atrioventricular (AV) block with idioventricular rhythm [49]; persistent or paroxysmal atrial fibrillation (AF), atrial flutter, atrial tachycardia [64]; paroxysmal supraventricular tachycardia (PSVT) [49]; DVT and silent PE [65]; platypnea-orthodeoxia [66]; abdominal pain without acute abdomen [64]; and delirium [67].

Other causes of SD strictly related to the respiratory system are:

- Massive hemoptysis. The common causes of massive hemoptysis could be generated by tuberculosis, bronchiectasis, lung abscesses, and mycetomas [68]; another important cause of massive hemoptysis is lung cancer that could generate this symptoms in about $20 \%$ of patients [69]. Moreover, cystic fibrosis is reported to be another cause of massive hemoptysis [70].

- $\quad$ Severe pneumonia. This cause is considered one of the natural causes of nc-SD [71]. It could be generated both by viral and bacterial agents, generating different diseases involving myocardial ischemia, a maladaptive response to hypoxia, sepsis-related cardiomyopathy, or other phenomena [72,73]. It is interesting to note that the recent pandemic infection of SARS-CoV-2 could generate severe pneumonia with subsequent cardiac arrest [74].

- $\quad$ Asthma. In a recent study performed in Denmark in young people with uncontrolled asthma, Gullach et al. [75] described that in their cohort, the predominant cause of death was SCD followed by a fatal asthma attack. This clarified the concept that asthma could be considered as a trigger for underlying unknown heart diseases [76].

- Anaphylaxis. Refers to the event cascade that may follow exposure to a particular antigen and causing an acute multi-organ response, with cardiac, coronary/systemic arterial, and dermatological involvement [77]. Cardiovascular symptoms can be the sole manifestation of food allergies, especially in cases where the tragic event occurs during exercise [78]; in similar cases, death may mimic SCD and only a complete autopsy with a full histological and immunohistochemical investigation may disclose the exact cause of death.

- Airway obstruction. Another important cause of nc-SD is hypoxia secondary to pulmonary processes, including small and large airway obstruction (bronchospasm, aspiration, foreign body, edema). Treating the cause of hypoxia/hypoxemia must 
be done quickly because this is one of the potentially reversible causes of cardiac arrest [79]. Proper oxygenation and ventilation are key to restoring adequate amounts of oxygen into the system and negating lethal cardiac rhythm [80]. It is important to note that accidental aspiration of an element into the airways is a widespread clinical scenario among children under 3 years old, and it represents the leading cause of infantile death [81].

\subsection{Central Nervous System}

Among the nc-SDs, an important category is the imbalance of the autonomic nervous system control of the cardiovascular system. For these reasons, several neurological conditions, such as stroke, epileptic attacks and brain trauma, drugs, and catecholamine toxicity, may be related to SD [82].

Stroke represents the first cause of SD in this category; it is possible to distinguish three kinds of stroke:

- Intracerebral hemorrhage (ICH) secondary to hypertension or other causes. ICH represents about $10 \%$ of strokes. Hypertension is the most important risk factor in order to determine the risk for ICH: for example, Roberts et al. described two cases who died from non-traumatic ICH [83]. Moreover, in a recent study, Verdecchia et al. remarked its value as an independent prognostic marker for SD in the long-term [84].

- Brain infarction secondary to atherosclerosis or embolism. Moreover, a strong positive relationship exists between decreased heart rate variability (HRV) and SD [85]. Brain infarction is implicated in causing diminished HRV and is strictly associated with symptomatic carotid disease [86].

- Subarachnoid hemorrhage (SAH), secondary to ruptured berry aneurysm or other causes. It represents about $5 \%$ of stroke, and smoking, high blood pressure, increasing age, and possibly female sex are independent risk factors for SAH [87].

Other than stroke causes include:

- Bacterial meningitis: despite advances in clinical care, it remains a severe disease with a high risk of complications that may lead to SD [88];

- $\quad$ Epilepsy: it is named sudden unexpected death in epilepsy (SUDEP), referring to the sudden and unexpected death of an epileptic patient with no other health issues during normal activity. The exact cause of SUDEP has not been established yet; however, it is assumed to be caused by multiple organ failure [89];

- Brain tumor: even if it represents a rare event, an undiagnosed primary brain tumor may be considered a risk factor for SD. For example, Riezzo et al. described three cases of SD due to glioblastoma [90].

\subsection{Abdominal Causes}

The abdominal region could be involved in the generation of SD. Indeed, even if these causes are a less common cause of SD when compared to other conditions, they are equally important [91,92]. Particularly, the prevalent cause of death involving the abdominal region is massive bleeding into the peritoneal cavity or gastrointestinal tract: it could be linked to different diseases such as duodenal ulcer, gastric ulcer, ulcerative colitis or diverticulitis, malignancy, ruptured ectopic pregnancy, and ruptured viscus for the presence of bowels (e.g., ovarian cysts) [93-95].

Moreover, nc-SD involving the abdominal region could be generated by other diseases such as acute liver failure [96] or acute pancreatitis [97].

\subsection{Endocrine System}

Even if rare, endocrine diseases should be closely related to nc-SD. Notably, when other causes are excluded, this tragic event may be related to different pathological statuses such as adrenal insufficiency (although infrequent, it may occur in individuals treated for other critical conditions where impairment of corticoadrenal function often happen) $[98,99]$, 
diabetic coma [100], severe hypothyroidism (myxedema) [101], parathyroid crisis [102,103], thymoma [104], etc.

\subsection{Iatrogenic}

The cases of nc-SD could be related to iatrogenic causes. In particular, even if it is frequently under-evaluated, it could be generated by problems related to prescription drugs [105]. Other causes may be related to the sudden withdrawal of steroids or other drugs. SD represents a complication of other tragic events related to medical errors, such as anesthesia or mismatched blood transfusion [106].

\subsection{Miscellaneous}

The so-defined miscellaneous category includes drug abuse: it could be related both to the assumption of controlled or uncontrolled substances [107]. In the first case, it is related to the assumption of legal drugs but with errors in the assumption (principally in older people) or voluntary wrong assumption (self-poisoning or for doping purposes), i.e., the use/abuse of anabolic-androgenic steroids (AAS). To date, AASs are frequently used not only to treat both hormonal diseases and other pathologies characterized by muscle loss, but by young people (athletes or individuals) to improve both physical appearance and performance $[108,109]$. AAS use/abuse is strictly related to the improved risk for SD $[110,111]$.

In the other case, it is related to the assumption of drugs for "recreational" purposes [112]. For example, cocaine in its various forms could be closely related to fatal cardiac arrhythmia, microvascular injury, and acute myocardial ischemia due to coronary vasospasm are the most important causes of cocaine-related SDs. The cardiotoxicity of cocaine is not limited to massive doses of the drug, and underlying heart disease is not a prerequisite for cocaine-related cardiac deaths. Moreover, cocaine is associated with many health complications, including gastrointestinal ischemia/infarction and hemorrhage. For this reason, its assumption may generate SD [113]. Other recreational drugs such as heroin [114], marijuana [115], potent synthetic cannabinoids [116], as well as psychotropic drugs consumed by young people [117] may be related to SDs. Moreover, the proportion of users of recreational drugs was unexpectedly high, even more prevalent than other cardiovascular risk factors. Toxic effects could play an important role as triggers of SD, particularly in young people.

Other miscellaneous nc-SDs could be generated by anaphylaxis or bacteremic shocks, shock from dread, fright or emotion (vagal inhibition), sickle cell crisis, alcoholism, etc. [118,119].

\subsection{Indeterminate}

This category is reserved for those cases in which the cause of death remains in doubt even after an exhaustive study. Notably, to date, although the progress in the diagnostic fields, several deaths have been classified with the term 'unascertained': this should be reserved for circumstances where the cause and manner of death remain undetermined after autopsy [120].

\section{Discussion}

The mission of the forensic pathologist is to establish the exact cause of death. As previously described, in the case of $\mathrm{SD}$, it represents a very complex task, although the scientific community has published professional guidelines, book chapters, and many scientific publications on this issue.

In the definition of SD, it is important to clarify the meaning of the term "unexplained": indeed, in common forensic practice, a "death" is defined "unexplained" only after an adequate post-mortem investigation. Obviously, from a forensic point of view, autopsy findings should be carefully evaluated as well as the crime scene investigation with the relative circumstances and the medical history of the victim. Even if the cause of death could remain unanswered after a thorough forensic investigation, from the medical standpoint 
it represents a critical situation with dangerous clinical implications. Particularly, SD potentially leaves family members at risk. In this scenario, the scientific community should improve efforts to define good practices in the case of SD. In this way, we suggest a practical forensic workflow that should be applied in every case of SD (Figure 2).

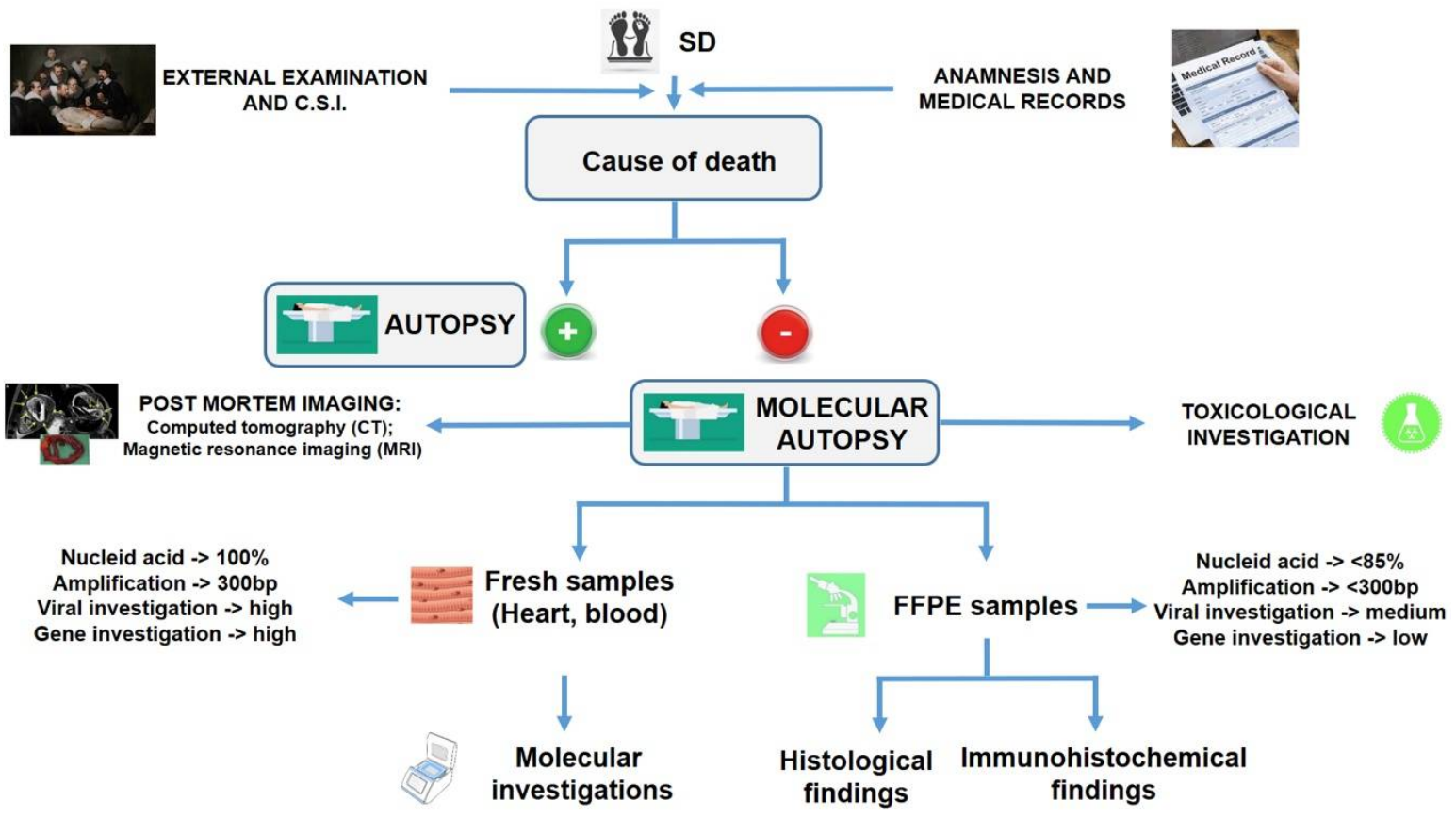

Figure 2. A practical flowchart that should be applied in all cases of SD.

When an SD occurs, several steps should be conducted by the forensic pathologist in order to ascertain the exact cause of death. Obviously, the first two steps that should be performed with greater attention are the external examination and the crime scene investigation (C.S.I.). In the same manner, it is important to collect all information about the anamnesis and/or medical records of the victim. In this regard, several important data should be collected, such as age, gender, occupation, and lifestyle of the victim; the circumstances of death, past medical history, the presence of previous cardiovascular interventions, possible prescription of therapeutical drugs, family cardiac history, possible data collected during the rescue intervention (ECG tracking, serological data, etc.). In all cases, an autopsy should be considered mandatory in order to ascertain the exact cause of death. Before autopsy, the pathologist should collect numerous data from the external examination of the body: it is important to establish body dimensions (weight and height), checking for any dysmorphic features, skin, hair, or skeletal abnormalities, including the presence of a pacemaker or other external interventions (recent intravenous access, intubation, defibrillation, etc.). It is mandatory that all external and internal injuries should be described and photographed. Based on literature data [9], the forensic pathologist is able to directly determine a conclusive cause of death after macroscopic evaluation (positive macroscopic autopsy) in about $65 \%$ of cases (green signal), while it remains undefined in the other cases with the so-called "inconclusive autopsy" (negative macroscopic autopsy), indicated with the red signal in the flowchart.

In the cases with a negative macroscopic autopsy, further investigations are needed, applying the so-called molecular autopsy to explain the cause of death. As summarized in this graph, in cases of SD, it should be considered mandatory to perform the so-called "molecular autopsy", meaning the application of molecular techniques to the post-mortem investigation. As summarized in the workflow, the samples collected during a standard autopsy protocol (fresh and/or fixed samples, for example, to perform toxicological and Microscopic Analysis) are used applying molecular techniques to identify hereditary 
diseases.In this context, it is important to stress the role of post-mortem imaging: several recent publications have reported the pivotal roles of computed tomography $(\mathrm{CT})$ and magnetic resonance imaging (MRI) in order to identify different organ damage before the autopsy [121-123]. The usefulness of traditional X-ray images and post-mortem computed tomography (PMCT) is useful in visualizing calcified plaques, hemopericardium, and valves, and in identifying and locating cardiovascular devices [124,125]. Moreover, by means of a radiological investigation, different heart abnormalities can be highlighted [126]. As recently reported, modern radiological methods, such as multiple detector computed tomography (MDCT), MDCT-angiography, and cardiac MRI have been introduced into post-mortem practice for the investigation of SD, including cases of SCD [127]. A recent retrospective study studied the role of forensic post-mortem CT in order to define the cause of death, especially in cases of acute heart insufficiency or respiratory failure [128].

In the same way, a toxicological investigation plays a pivotal role in excluding the presence of exogenous substances that could be strictly related to SDs. Clinical and forensic toxicology represent two disciplines involving the quantification of xenobiotics in different biological and non-biological samples in order to define the diagnosis, treatment, prognosis and prevention of poisonings and to identify causes or contributory causes of death in cases of fatal intoxications [129]. The samples that could be collected to perform the toxicological investigation are: peripheral venous blood, vitreous humor, hair, urine, bile, pericardial/cerebrospinal fluids, and gastric contents. In a recent cohort study, Bjune et al. [130] reported that SCD victims with positive post-mortem toxicological findings showed polypharmacy assumption, showing this condition may play a proarrhythmic role in these cases. In 2019 Rippoll et al. reported that out of 101 enrolled SD cases, 52 showed positive toxicological findings. Ethanol was the most used substance, followed by legal drugs (meaning therapeutic drugs) and drugs of abuse. In general, the most used toxic substances are illegal drugs (especially cocaine), ethanol, tobacco, doping substances, and therapeutic drugs in not-recommended dosages [131]. Many prescribed drugs or illicit substances exert their adverse effects, both acute and chronic, on heart tissues: for these reasons, toxicological data are strictly related to the histopathological alterations of heart tissue [108,132-135].

As previously described, SD could represent the first manifestation of an unknown inherited cardiac disease. In similar cases, by applying genetic testing, it could be possible to discover the causality, with the identification of family member carriers, adopting preventive strategies $[136,137]$. Despite the fact that molecular autopsy is recommended in the guidelines for post-mortem investigation of SD, this is rarely performed, maybe because of the necessity to have a specialist laboratory $[2,138]$. Indeed, it is usually performed in cases of research projects, performing the analysis of the most prevalent genes associated with channelopathies (such as KCNQ1, KCNH2, SCN5A, and others), excluding other important candidate genes [18,139-144]. Moreover, in a recent article by Marey et al. [145], the pivotal role of post-mortem molecular testing in the strategy of family care after SD is remarked, particularly in suspected cardiomyopathy, since genetic findings provide additional useful information for relatives, which are beyond a conventional autopsy. In the last few years, the development of next-generation sequencing (NGS), which represents high-throughput genetic technology, has allowed the investigation of many candidate genes, reducing the bias of untested genomic regions [146]. The main problem related to NGS technologies is the necessity of ultra-specialist personnel and the costs. Indeed, to date, only a few studies have been performed proving the efficacy of this molecular approach in cases of SD [147-149]. In order to perform a molecular investigation, it should be mandatory to sample the victim's body with different specimens, such as blood or other fresh tissues: indeed, the gold standard for molecular genetic testing is EDTA blood or fresh frozen tissue (heart, liver, and spleen) [150]. As summarized in Figure 2, formalin fixation and paraffin embedding (FFPE) of tissues are not recommended for molecular investigations, even if in the last few years technologies have improved the results obtained using these materials. Obviously, these samples are very important in order to perform 
histological and immunohistochemical investigations. These techniques are commonly used to highlight tissue damage; moreover, in SD cases, they should be used to identify different organ damage and/or the etiology in the myocarditis generated by different external agents, such as viral or bacterial infection: for example, the molecular techniques are the gold standard methods to diagnose viral myocarditis [151-154]. Identification of hereditary diseases is very important to extend the genetic analysis to members of the family of the deceased subject. An extensive, multigenerational family history offers the potential to improve every aspect of care: from establishing a diagnosis, to developing a genetic testing approach, to interpreting genetic test results, to continuously assessing the risk of SCD. Family history reconstruction could be considered not simply a static account of deaths and pre-existing diagnoses, but an ongoing dynamic process that incorporates new and valuable insights from family medical records, clinical cardiology assessments, genetic testing, and visual analysis of the deceased's family tree [155].

In light of these data, following the suggested flowchart step-by-step, the forensic pathologist will be able to apply all the indications of the scientific community to real cases. Particularly, the data discussed in this narrative review suggest that autopsy should be considered mandatory in cases of SD. In this way, it will be possible to answer all questions relative to a SD: such as the death may be attributable to cardiac disease or to other causes, the nature of the cardiac disease (defining whether the mechanism was arrhythmic or mechanical), whether the condition causing SD may be inherited (with the subsequent genetic counseling), the assumption of toxic or illicit drugs, the presence of trauma, and other unnatural causes.

\section{Conclusions}

Based on this review, it should be stated that a Coroner's post-mortem must be carried out in all cases in which SD occurs if the cause of death is unknown; obviously, in similar cases, the relative medical certificate of cause of death will not be forthcoming. Although forensic investigations may determine the cause of death in most cases, about $19 \%$ of cases remain unsolved, requiring further investigation. The molecular autopsy, thanks to modern technologies such as NGS, may help identify the cause of death in a large percentage of unsolved cases. The identification of new risk markers of SD remains one of the most important research fields for the scientific community [85]. For these reasons, a multidisciplinary working group of cardiologists, forensic experts, pathologists, intensive care specialists, geneticists, molecular biologists, and toxicologists is required [156]. Indeed, all clinical and forensic disciplines should build bridges between themselves [129]. Increasing relationships are improving the growth, reliability and the robustness of both kinds of laboratories.

In this context, it is interesting to report the experience of the Swiss Society of Legal Medicine, which in 2015 created a multidisciplinary working group composed of clinical and molecular geneticists together with cardiologists, in the hope of harmonizing the approach to the investigation of SCD [138]. This idea is strongly recommended in the guidelines for autopsy investigation of sudden cardiac death: the authors suggested their adoption throughout Europe with the aim of improving the standards of autopsy practice; moreover, they suggest the development of regional multidisciplinary networks of cardiologists, geneticists, and pathologists to collect more useful information [2]. Molecular medicine represents an important tool to improve the quality of death investigations, providing a new lens to better define the exact cause of death improving traditional methods [157]. Indeed, it is important to stress the key role that the medico-legal investigation has in SD investigations, not only in order to identify the exact cause of death but to indicate prevention in family members: high-resolution variant interpretation provides diagnostic accuracy and healthcare efficiency [158]. The autopsy report should conclude with a clear clinicopathological summary of the major positive findings and their relationship to the cause of death. Indeed, considering the importance of the genetic substrate, particularly in 
the case of $\mathrm{SCD}$, the identification of mutations of lethal and inheritable cardiomyopathies and cardiac channelopathies can be applied in healthcare management.

Finally, it is important to remark that several causes of death remain unexplained after careful macroscopic, microscopic, and laboratory analyses: in this context, it should be considered mandatory to improve the research activity in this particular field, facilitating the identification of novel causes, and emerging patterns of diseases, causing SCD. In this way, each country should generate a multidisciplinary expert network to allow the interchange of knowledge in order to reduce "unexplained" deaths. Moreover, as recently suggested by Paratz et al. [159], another advisable action that could be adopted is the use of comprehensive multisource surveillance SCD registries that, even while they are not currently widespread, remain an appropriate method.

Author Contributions: Conceptualization, F.S., M.E., G.M., and M.S..; methodology, F.S., G.M., M.E., N.D.N., G.D.M., and M.S.; validation, F.S., G.M., and M.S.; formal analysis, F.S., G.M., M.E., N.D.N., G.D.M., and M.S.; investigation, F.S., G.M., and M.S.; data curation, F.S., G.M., and M.S.; writingoriginal draft preparation, F.S., G.M., and M.S.; writing-review and editing, F.S., G.M., and M.S. All authors have read and agreed to the published version of the manuscript.

Funding: This research received no external funding.

Institutional Review Board Statement: Not applicable.

Informed Consent Statement: Not applicable.

Data Availability Statement: Data sharing is not applicable to this article.

Acknowledgments: The authors thank the Scientific Bureau of the University of Catania for language support.

Conflicts of Interest: The authors declare no conflict of interest.

\section{References}

1. WHO ICD-11 for Mortality and Morbidity Statistics. Available online: https://icd.who.int/browse11/l-m/en\#/http $\% 3 \mathrm{~A} \% 2 \mathrm{~F} \%$ 2Fid.who.int \%2Ficd\%2Fentity\%2F426429380 (accessed on 30 June 2021).

2. Basso, C.; Association for European Cardiovascular Pathology; Aguilera, B.; Banner, J.; Cohle, S.; D'Amati, G.; De Gouveia, R.H.; Di Gioia, C.; Fabre, A.; Gallagher, P.J.; et al. Guidelines for autopsy investigation of sudden cardiac death: 2017 update from the Association for European Cardiovascular Pathology. Virchows Arch. 2017, 471, 691-705. [CrossRef]

3. Tang, Y.; Siegel, D.; Sampson, B. Molecular Investigations of Sudden Unexplained Deaths. Acad. Forensic Pathol. $2011,1,194-201$. [CrossRef]

4. Lambert, A.B.E.; Parks, S.E.; Camperlengo, L.; Cottengim, C.; Anderson, R.L.; Covington, T.M.; Shapiro-Mendoza, C.K. Death Scene Investigation and Autopsy Practices in Sudden Unexpected Infant Deaths. J. Pediatr. 2016, 174, 84-90.e1. [CrossRef] [PubMed]

5. Zhuo, L.; Zhang, Y.; Zielke, H.R.; Levine, B.; Zhang, X.; Chang, L.; Fowler, D.; Li, L. Sudden unexpected death in epilepsy: Evaluation of forensic autopsy cases. Forensic Sci. Int. 2012, 223, 171-175. [CrossRef] [PubMed]

6. Bennett, T.; Martin, L.J.; Heathfield, L.J. A retrospective study of death scene investigation practices for sudden unexpected death of infants (SUDI) in Cape Town, South Africa. Forensic Sci. Med. Pathol. 2019, 16, 49-56. [CrossRef] [PubMed]

7. Brugada, R.; Brugada, J.; Brugada, P. Clinical Approach to Sudden Cardiac Death Syndromes; Springer: London, UK, 2010; ISBN 9781848829268.

8. Roncati, L.; Manenti, A.; Barbolini, G. Sudden death. In Advances in Health and Disease; Nova Science: Hauppauge, NY, USA, 2018; ISBN 9781536130218.

9. Sanchez, O.; Campuzano, O.; Fernández-Falgueras, A.; Sarquella-Brugada, G.; Cesar, S.; Mademont, I.; Mates, J.; Pérez-Serra, A.; Coll, M.; Pico, F.; et al. Natural and undetermined sudden death: Value of post-mortem genetic investigation. PLoS ONE 2016, 11, e0167358. [CrossRef] [PubMed]

10. Maron, B.J.; Mackey-Bojack, S.; Facile, E.; Duncanson, E.; Rowin, E.J.; Maron, M.S. Hypertrophic Cardiomyopathy and Sudden Death Initially Identified at Autopsy. Am. J. Cardiol. 2020, 127, 139-141. [CrossRef]

11. Wong, L.C.H.; Behr, E.R. Sudden unexplained death in infants and children: The role of undiagnosed inherited cardiac conditions. EP Eur. 2014, 16, 1706-1713. [CrossRef] [PubMed]

12. Kong, M.H.; Fonarow, G.; Peterson, E.D.; Curtis, A.B.; Hernandez, A.F.; Sanders, G.D.; Thomas, K.L.; Hayes, D.L.; Al-Khatib, S.M. Systematic Review of the Incidence of Sudden Cardiac Death in the United States. J. Am. Coll. Cardiol. 2011, 57, 794-801. [CrossRef] 
13. Gräsner, J.-T.; Bossaert, L. Epidemiology and management of cardiac arrest: What registries are revealing. Best Pract. Res. Clin. Anaesthesiol. 2013, 27, 293-306. [CrossRef]

14. Al-Khatib, S.M.; Stevenson, W.G.; Ackerman, M.J.; Bryant, W.J.; Callans, D.J.; Curtis, A.B.; Deal, B.J.; Dickfeld, T.; Field, M.E.; Fonarow, G.C.; et al. 2017 AHA/ACC/HRS Guideline for Management of Patients with Ventricular Arrhythmias and the Prevention of Sudden Cardiac Death: Executive Summary: A Report of the American College of Cardiology/American Heart Association Task Force on Clinical Practice Gui. J. Am. Coll. Cardiol. 2018, 15, e190-e252. [CrossRef] [PubMed]

15. Bagnall, R.; Weintraub, R.G.; Ingles, J.; Duflou, J.; Yeates, L.; Lam, L.; Davis, A.M.; Thompson, T.; Connell, V.; Wallace, J.; et al. A Prospective Study of Sudden Cardiac Death among Children and Young Adults. N. Engl. J. Med. 2016, 374, 2441-2452. [CrossRef] [PubMed]

16. Fineschi, V.; Michalodimitrakis, M.; D’Errico, S.; Neri, M.; Pomara, C.; Riezzo, I.; Turillazzi, E. Insight into stress-induced cardiomyopathy and sudden cardiac death due to stress. A forensic cardio-pathologist point of view. Forensic Sci. Int. 2010, 194, 1-8. [CrossRef] [PubMed]

17. Rodríguez-Calvo, M.S.; Brion, M.; Allegue, C.; Concheiro, L.; Carracedo, A. Molecular genetics of sudden cardiac death. Forensic Sci. Int. 2008, 182, 1-12. [CrossRef] [PubMed]

18. Pellegrino, P.L.; Bafunno, V.; Ieva, R.; Brunetti, N.D.; Mavilio, G.; Sessa, F.; Grimaldi, M.; Margaglione, M.; Di Biase, M. A Novel Mutation in Human Ether-a-Go-Go-Related Gene, Alanine to Proline at Position 490, Found in a Large Family with Autosomal Dominant Long QT Syndrome. Am. J. Cardiol. 2007, 99, 1737-1740. [CrossRef] [PubMed]

19. Barletta, V.; Fabiani, I.; Lorenzo, C.; Nicastro, I.; Bello, V. Di Sudden cardiac death: A review focused on cardiovascular imaging. J. Cardiovasc. Echogr. 2014, 24, 41-51. [CrossRef]

20. Campuzano, O.; Allegue, C.; Partemi, S.; Iglesias, A.; Oliva, A.; Brugada, R. Negative autopsy and sudden cardiac death. Int. J. Leg. Med. 2014, 128, 599-606. [CrossRef] [PubMed]

21. Bogle, B.M.; Ning, H.; Mehrotra, S.; Goldberger, J.J.; Lloyd-Jones, D.M. Lifetime Risk for Sudden Cardiac Death in the Community. J. Am. Hear. Assoc. 2016, 5, e002398. [CrossRef] [PubMed]

22. Elkilany, G.; Singh, R.B.; Adeghate, E.; Singh, J.; Bidasee, K.; Shehab, O.; Hristova, K. Sudden cardiac death. World Heart J. 2017, 9 , $51-62$.

23. Osman, J.; Tan, S.C.; Lee, P.Y.; Low, T.Y.; Jamal, R. Sudden Cardiac Death (SCD)—Risk stratification and prediction with molecular biomarkers. J. Biomed. Sci. 2019, 26, 1-12. [CrossRef]

24. Ettehad, D.; Emdin, C.A.; Kiran, A.; Anderson, S.G.; Callender, T.; Emberson, J.; Chalmers, J.; Rodgers, A.; Rahimi, K. Blood pressure lowering for prevention of cardiovascular disease and death: A systematic review and meta-analysis. Lancet 2016, 387, 957-967. [CrossRef]

25. Hess, P.L.; Al-Khalidi, H.R.; Friedman, D.J.; Mulder, H.; Kucharska-Newton, A.; Rosamond, W.R.; Lopes, R.D.; Gersh, B.J.; Mark, D.B.; Curtis, L.H.; et al. The Metabolic Syndrome and Risk of Sudden Cardiac Death: The Atherosclerosis Risk in Communities Study. J. Am. Heart Assoc. 2017, 6. [CrossRef]

26. Mukamal, K.J. The Effects of Smoking and Drinking on Cardiovascular Disease and Risk Factors. Alcohol Res. Health 2006, 29, 199-202.

27. Vos, A.; van der Wal, A.C.; Teeuw, A.H.; Bras, J.; Vink, A.; Nikkels, P.G.J. Cardiovascular causes of sudden unexpected death in children and adolescents (0-17 years): A nationwide autopsy study in the Netherlands. Netherlands Hear. J. 2018, 26, 500-505. [CrossRef] [PubMed]

28. Tester, D.J.; Ackerman, M.J. The molecular autopsy: Should the evaluation continue after the funeral? Pediatric Cardiol. 2012, 33, 461-470. [CrossRef] [PubMed]

29. Ackerman, M.J. State of Postmortem Genetic Testing Known as the Cardiac Channel Molecular Autopsy in the Forensic Evaluation of Unexplained Sudden Cardiac Death in the Young. Pacing Clin. Electrophysiol. 2009, 32, S86-S89. [CrossRef] [PubMed]

30. Semsarian, C.; Ingles, J.; Wilde, A.A. Sudden cardiac death in the young: The molecular autopsy and a practical approach to surviving relatives. Eur. Heart J. 2015, 36, 1290-1296. [CrossRef]

31. Neri, M.; Di Donato, S.; Maglietta, R.; Pomara, C.; Riezzo, I.; Turillazzi, E.; Fineschi, V. Sudden death as presenting symptom caused by cardiac primary multicentric left ventricle rhabdomyoma, in an 11-month-old baby. An immunohistochemical study. Diagn. Pathol. 2012, 7, 169. [CrossRef]

32. Magi, S.; Lariccia, V.; Maiolino, M.; Amoroso, S.; Gratteri, S. Sudden cardiac death: Focus on the genetics of channelopathies and cardiomyopathies. J. Biomed. Sci. 2017, 24, 1-18. [CrossRef]

33. Campuzano, O.; Sarquella-Brugada, G.; Brugada, R.; Brugada, J. Genetics of channelopathies associated with sudden cardiac death. Glob. Cardiol. Sci. Pract. 2015, 2015, 39. [CrossRef]

34. Van Niekerk, C.; Van Deventer, B.S.; Du Toit-Prinsloo, L. Long QT syndrome and sudden unexpected infant death. J. Clin. Pathol. 2017, 70, 808-813. [CrossRef]

35. Care, M.; Chauhan, V.; Spears, D. Genetic Testing in Inherited Heart Diseases: Practical Considerations for Clinicians. Curr. Cardiol. Rep. 2017, 19, 88. [CrossRef]

36. Bezzina, C.R.; Lahrouchi, N.; Priori, S.G. Genetics of Sudden Cardiac Death. Circ. Res. 2015, 116, 1919-1936. [CrossRef]

37. Junttila, M.J.; Holmström, L.; Pylkäs, K.; Mantere, T.; Kaikkonen, K.; Porvari, K.; Kortelainen, M.L.; Pakanen, L.; Kerkelä, R.; Myerburg, R.J.; et al. Primary Myocardial Fibrosis as an Alternative Phenotype Pathway of Inherited Cardiac Structural Disorders. Circulation 2018, 137, 2716-2726. [CrossRef] 
38. Sarquella-Brugada, G.; Campuzano, O.; Cesar, S.; Iglesias, A.; Fernandez, A.; Brugada, J.; Brugada, R. Sudden infant death syndrome caused by cardiac arrhythmias: Only a matter of genes encoding ion channels? Int. J. Legal Med. 2016, 130, 415-420. [CrossRef] [PubMed]

39. Cafarelli, F.P.; Macarini, L.; Cipolloni, L.; Maglietta, F.; Guglielmi, G.; Sessa, F.; Pennisi, A.; Cantatore, S.; Bertozzi, G. Ex situ heart magnetic resonance imaging and angiography: Feasibility study for forensic purposes. Forensic Imaging 2021, $25,200442$. [CrossRef]

40. Hernández-Romero, D.; Valverde-Vázquez, M.D.R.; Hernández Del Rincón, J.P.; Noguera-Velasco, J.A.; Pérez-Cárceles, M.D.; Osuna, E. Diagnostic Application of Postmortem Cardiac Troponin I Pericardial Fluid/Serum Ratio in Sudden Cardiac Death. Diagnostics 2021, 11, 614. [CrossRef] [PubMed]

41. Turillazzi, E.; Di Paolo, M.; Neri, M.; Riezzo, I.; Fineschi, V. A theoretical timeline for myocardial infarction: Immunohistochemical evaluation and western blot quantification for Interleukin-15 and Monocyte chemotactic protein-1 as very early markers. J. Transl. Med. 2014, 12, 188. [CrossRef] [PubMed]

42. Ullal, A.J.; Abdelfattah, R.S.; Ashley, E.A.; Froelicher, V.F. Hypertrophic Cardiomyopathy as a Cause of Sudden Cardiac Death in the Young: A Meta-Analysis. Am. J. Med. 2016, 129, 486-496.e2. [CrossRef]

43. Basso, C.; Maron, B.J.; Corrado, D.; Thiene, G. Clinical profile of congenital coronary artery anomalies with origin from the wrong aortic sinus leading to sudden death in young competitive athletes. J. Am. Coll. Cardiol. 2000, 35, 1493-1501. [CrossRef]

44. Glorioso, J.; Reeves, M. Marfan syndrome: Screening for sudden death in athletes. Curr. Sports Med. Rep. 2002, 1, 67-74. [CrossRef]

45. De Backer, J. Cardiovascular characteristics in Marfan syndrome and their relation to the genotype. Verh. K. Acad. Geneeskd. Belg. 2009, 71, 335-371. [PubMed]

46. Aalberts, J.J.; van Tintelen, J.P.; Meijboom, L.J.; Polko, A.; Jongbloed, J.D.; van der Wal, H.; Pals, G.; Osinga, J.; Timmermans, J.; De Backer, J.; et al. Relation between genotype and left-ventricular dilatation in patients with Marfan syndrome. Gene 2014, 534, 40-43. [CrossRef] [PubMed]

47. Rueda, M.; Wagner, J.L.; Phillips, T.C.; Topol, S.E.; Muse, E.D.; Lucas, J.R.; Wagner, G.N.; Topol, E.J.; Torkamani, A. Molecular Autopsy for Sudden Death in the Young: Is Data Aggregation the Key? Front. Cardiovasc. Med. 2017, 4, 72. [CrossRef] [PubMed]

48. Suktitipat, B.; Sathirareuangchai, S.; Roothumnong, E.; Thongnoppakhun, W.; Wangkiratikant, P.; Vorasan, N.; Krittayaphong, R.; Pithukpakorn, M.; Boonyapisit, W. Molecular investigation by whole exome sequencing revealed a high proportion of pathogenic variants among Thai victims of sudden unexpected death syndrome. PLoS ONE 2017, 12, e0180056. [CrossRef] [PubMed]

49. Morrone, D.; Morone, V. Acute pulmonary embolism: Focus on the clinical picture. Korean Circ. J. 2018, 48, 365-381. [CrossRef] [PubMed]

50. Stein, P.D.; Henry, J.W. Clinical Characteristics of Patients with Acute Pulmonary Embolism Stratified According to Their Presenting Syndromes. Chest 1997, 112, 974-979. [CrossRef]

51. Islam, M.; Filopei, J.; Frank, M.; Ramesh, N.; Verzosa, S.; Ehrlich, M.; Bondarsky, E.; Miller, A.; Steiger, D. Pulmonary infarction secondary to pulmonary embolism: An evolving paradigm. Respirology 2018, 23, 866-872. [CrossRef] [PubMed]

52. Dalen, J.E.; Alpert, J.S. Natural history of pulmonary embolism. Prog. Cardiovasc. Dis. 1975, 17, 259-270. [CrossRef]

53. Karia, S.; Screaton, N. Pulmonary embolism. In Imaging; Barr, R.G., Parr, D.G., Vogel-Claussen, J., Eds.; ERS Monograph: Lausanne, Switzerland, 2015.

54. D’Errico, S.; Zanon, M.; Montanaro, M.; Radaelli, D.; Sessa, F.; Di Mizio, G.; Montana, A.; Corrao, S.; Salerno, M.; Pomara, C. More than Pneumonia: Distinctive Features of SARS-CoV-2 Infection. From Autopsy Findings to Clinical Implications: A Systematic Review. Microorganisms 2020, 8, 1642. [CrossRef]

55. Cipolloni, L.; Sessa, F.; Bertozzi, G.; Baldari, B.; Cantatore, S.; Testi, R.; D’Errico, S.; Di Mizio, G.; Asmundo, A.; Castorina, S.; et al. Preliminary Post-Mortem COVID-19 Evidence of Endothelial Injury and Factor VIII Hyperexpression. Diagnostics 2020, 10, 575. [CrossRef] [PubMed]

56. Sessa, F.; Salerno, M.; Pomara, C. Autopsy Tool in Unknown Diseases: The Experience with Coronaviruses (SARS-CoV, MERS-CoV, SARS-CoV-2). Medicina 2021, 57, 309. [CrossRef] [PubMed]

57. Geibel, A.; Zehender, M.; Kasper, W.; Olschewski, M.; Klima, C.; Konstantinides, S. Prognostic value of the ECG on admission in patients with acute major pulmonary embolism. Eur. Respir. J. 2005, 25, 843-848. [CrossRef]

58. Xu, K.; Tang, X.; Song, Y.; Chen, Z. The Diagnostic Dilemma between Pulmonary Embolism with Positive Chest Imaging and Pneumonia: A Case Report and Literature Review. J. Transl. Med. Epidemiol. 2015, 3, 1039.

59. Wood, K.E. Major pulmonary embolism: Review of a pathophysiologic approach to the golden hour of hemodynamically significant pulmonary embolism. Chest 2002, 121, 877-905. [CrossRef]

60. Manne, J.R.R. Acute ST segment elevation in a patient with massive pulmonary embolism mimicking acute left main coronary artery obstruction. J. Am. Coll. Cardiol. 2016, 67, 1118. [CrossRef]

61. Kosuge, M.; Ebina, T.; Hibi, K.; Tsukahara, K.; Iwahashi, N.; Gohbara, M.; Matsuzawa, Y.; Okada, K.; Morita, S.; Umemura, S.; et al. Differences in negative $\mathrm{T}$ waves among acute coronary syndrome, acute pulmonary embolism, and Takotsubo cardiomyopathy. Eur. Heart J. Acute Cardiovasc. Care 2012, 1, 349-357. [CrossRef] [PubMed]

62. Omar, H.R. ST-segment elevation in V1-V4 in acute pulmonary embolism: A case presentation and review of literature. Eur. Heart J. Acute Cardiovasc. Care 2016, 5, 579-586. [CrossRef] [PubMed]

63. Duplyakov, D.; Kurakina, E.; Pavlova, T.; Khokhlunov, S.; Surkova, E. Value of syncope in patients with high-to-intermediate risk pulmonary artery embolism. Eur. Heart J. Acute Cardiovasc. Care 2015, 4, 353-358. [CrossRef] 
64. Inouye, S.K. Delirium in Older Persons. N. Engl. J. Med. 2006, 318, 1161-1174. [CrossRef]

65. Laack, T.A.; Goyal, D.G. Pulmonary embolism: An unsuspected killer. Emerg. Med. Clin. N. Am. 2004, 22, 961-983. [CrossRef] [PubMed]

66. Søgaard, K.; Schmidt, M.; Pedersen, L. Thirty-Year Mortality After Venous Thromboembolism: A Population-Based Cohort Study. J. Vasc. Surg. 2015, 61, 281. [CrossRef]

67. Carrascosa, M.F.; Batán, A.M.; Novo, M.F.A. Delirium and pulmonary embolism in the elderly. Mayo Clin. Proc. 2009, 84, 91-92. [CrossRef]

68. Corey, R.; Hla, K.M. Major and Massive Hemoptysis: Reassessment of Conservative Management. Am. J. Med. Sci. 1987, 294, 301-309. [CrossRef] [PubMed]

69. Kvale, P.A.; Selecky, P.A.; Prakash, U.B.S. Palliative care in lung cancer: ACCP evidence-based clinical practice guidelines (2nd edition). Chest 2007, 132, 368S-403S. [CrossRef] [PubMed]

70. Radchenko, C.; Alraiyes, A.H.; Shojaee, S. A systematic approach to the management of massive hemoptysis. J. Thorac. Dis. 2017, 9, S1069-S1086. [CrossRef]

71. Fineschi, V.; Turillazzi, E. Natural Causes of Sudden Death: Noncardiac. In Wiley Encyclopedia of Forensic Science; Wiley: Hoboken, NJ, USA, 2009. [CrossRef]

72. Smith, M.E.B.; Chiovaro, J.C.; O’Neil, M.; Kansagara, D.; Quiñones, A.R.; Freeman, M.; Motu'apuaka, M.L.; Slatore, C.G. Early warning system scores for clinical deterioration in hospitalized patients: A systematic review. Ann. Am. Thorac. Soc. 2014, 11, 1454-1465. [CrossRef]

73. Carr, G.E.; Yuen, T.C.; McConville, J.F.; Kress, J.P.; VandenHoek, T.L.; Hall, J.B.; Edelson, D.P. Early Cardiac Arrest in Patients Hospitalized with Pneumonia: A Report From the American Heart Association's Get With the Guidelines-Resuscitation Program. Chest 2012, 141, 1528-1536. [CrossRef]

74. Shirazi, S.; Mami, S.; Mohtadi, N.; Ghaysouri, A.; Tavan, H.; Nazari, A.; Kokhazadeh, T.; Mollazadeh, R. Sudden cardiac death in COVID-19 patients, a report of three cases. Future Cardiol. 2021, 17, 113-118. [CrossRef]

75. Gullach, A.J.; Risgaard, B.; Lynge, T.H.; Jabbari, R.; Glinge, C.; Haunsø, S.; Backer, V.; Winkel, B.G.; Tfelt-Hansen, J. Sudden death in young persons with uncontrolled asthma-A nationwide cohort study in Denmark. BMC Pulm. Med. 2015, 15, 1-8. [CrossRef]

76. Charlier, P.; Naneix, A.; Brun, L.; Álvarez, J.; De La Grandmaison, G.L. Asthma-related sudden death: Clinicopathological features in 14 cases. Rev. Médecine Légale 2012, 3, 115-119. [CrossRef]

77. Pravettoni, V.; Incorvaia, C. Diagnosis of exercise-induced anaphylaxis: Current insights. J. Asthma Allergy 2016, 9, 191-198. [CrossRef]

78. Flannagan, L.M.; Wolf, B.C. Sudden death associated with food and exercise. J. Forensic Sci. 2004, 49, 1-3. [CrossRef]

79. Heim, S.W.; Maughan, K.L. Foreign bodies in the ear, nose, and throat. Am. Fam. Physician 2007, 76, 121-123.

80. Zhang, L.; Yin, Y.; Zhang, J.; Zhang, H. Removal of foreign bodies in children's airways using flexible bronchoscopic CO2cryotherapy. Pediatric Pulmonol. 2016, 51, 943-949. [CrossRef] [PubMed]

81. Salih, A.M.; AlFaki, M.; Alam-Elhuda, D.M. Airway foreign bodies: A critical review for a common pediatric emergency. World J. Emerg. Med. 2016, 7, 5-12. [CrossRef] [PubMed]

82. Japundžić-Žigon, N.; Šarenac, O.; Lozić, M.; Vasić, M.; Tasić, T.; Bajić, D.; Kanjuh, V.; Murphy, D. Sudden death: Neurogenic causes, prediction and prevention. Eur. J. Prev. Cardiol. 2018, 25, 29-39. [CrossRef]

83. Roberts, C.C.; Snipes, G.J.; Ko, J.M.; Roberts, W.C.; Guileyardo, J.M. Nontraumatic intracerebral hemorrhage unassociated with arterial aneurysmal rupture as a cause of sudden unexpected death. Bayl. Univ. Med Cent. Proc. 2014, 27, 331-333. [CrossRef] [PubMed]

84. Verdecchia, P.; Angeli, F.; Cavallini, C.; Aita, A.; Turturiello, D.; De Fano, M.; Reboldi, G. Sudden Cardiac Death in Hypertensive Patients. Hypertension 2019, 73, 1071-1078. [CrossRef]

85. Sessa, F.; Anna, V.; Messina, G.; Cibelli, G.; Monda, V.; Marsala, G.; Ruberto, M.; Biondi, A.; Cascio, O.; Bertozzi, G.; et al. Heart rate variability as predictive factor for sudden cardiac death. Aging 2018, 10, 166-177. [CrossRef]

86. Algra, A.; Gates, P.C.; Fox, A.J.; Hachinski, V.; Barnett, H.J. Side of Brain Infarction and Long-Term Risk of Sudden Death in Patients with Symptomatic Carotid Disease. Stroke 2003, 34, 2871-2875. [CrossRef]

87. Lindbohm, J.V.; Kaprio, J.; Jousilahti, P.; Salomaa, V.; Korja, M. Risk Factors of Sudden Death from Subarachnoid Hemorrhage. Stroke 2017, 48, 2399-2404. [CrossRef] [PubMed]

88. Sharew, A.; Bodilsen, J.; Hansen, B.R.; Nielsen, H.; Brandt, C.T. The cause of death in bacterial meningitis. BMC Infect. Dis. 2020 20, 1-9. [CrossRef]

89. Seo, M.H.; Sung, W.Y. A case of near-sudden unexpected death in epilepsy due to ventricular fibrillation. Open Access Emerg. Med. 2019, 11, 161-166. [CrossRef] [PubMed]

90. Riezzo, I.; Zamparese, R.; Neri, M.; De Stefano, F.; Parente, R.; Pomara, C.; Turillazzi, E.; Ventura, F.; Fineschi, V. Sudden, unexpected death due to glioblastoma: Report of three fatal cases and review of the literature. Diagn. Pathol. 2013, 8, 73. [CrossRef] [PubMed]

91. Menezes, R.G.; Ahmed, S.; Pasha, S.B.; Hussain, S.A.; Fatima, H.; Kharoshah, M.A.; Madadin, M. Gastrointestinal causes of sudden unexpected death: A review. Med. Sci. Law 2017, 58, 5-15. [CrossRef]

92. Pomara, C.; Bello, S.; D’Errico, S.; Greco, M.; Fineschi, V. Sudden death due to a dissecting intramural hematoma of the esophagus (DIHE) in a woman with severe neurofibromatosis-related scoliosis. Forensic Sci. Int. 2013, 228, e71-e75. [CrossRef] 
93. Kibayashi, K.; Sumida, T.; Shojo, H.; Tokunaga, O. Unexpected death due to intestinal obstruction by a duplication cyst in an infant. Forensic Sci. Int. 2007, 173, 175-177. [CrossRef]

94. Lambert, M.P.; Heller, D.; Bethel, C. Extensive Gastric Heterotopia of the Small Intestine Resulting in Massive Gastrointestinal Bleeding, Bowel Perforation, and Death: Report of a Case and Review of the Literature. Pediatric Dev. Pathol. 2000, 3, $277-280$. [CrossRef]

95. Menezes, R.G.; Padubidri, J.R.; Babu, Y.R.; Naik, R.; Kanchan, T.; Senthilkumaran, S.; Chawla, K. Sudden unexpected death due to strangulated inguinal hernia. Medico-Legal J. 2016, 84, 101-104. [CrossRef]

96. Bernal, W.; Auzinger, G.; Dhawan, A.; Wendon, J. Acute liver failure. Lancet 2010, 376, 190-201. [CrossRef]

97. Stoppacher, R. Sudden Death Due to Acute Pancreatitis. Acad. Forensic Pathol. 2018, 8, 239-255. [CrossRef] [PubMed]

98. Palmiere, C. Sudden death due to acute adrenal crisis. Forensic Sci. Med. Pathol. 2015, 11, 629. [CrossRef] [PubMed]

99. D’Errico, S.; Pomara, C.; Riezzo, I.; Neri, M.; Turillazzi, E.; Fineschi, V. Cardiac failure due to epinephrine-secreting pheochromocytoma: Clinical, laboratory and pathological findings in a sudden death. Forensic Sci. Int. 2009, 187, e13-e17. [CrossRef]

100. Kjærulff, M.L.B.G.; Astrup, B.S. Sudden death due to diabetic ketoacidosis following power failure of an insulin pump: Autopsy and pump data. J. Forensic Leg. Med. 2019, 63, 34-39. [CrossRef] [PubMed]

101. Quirante, F.A.P.; Pastor-Pérez, F.J.; Manzano-Fernández, S.; Rivas, N.L.; Pérez, P.P.; Hernández, J.P.; Blanes, J.G. Unexpected autopsy findings after sudden cardiac death: Cardiovascular myxoedema and endocardial fibroelastosis. Int. J. Cardiol. 2015, 182, 281-283. [CrossRef]

102. Kiewiet, R.M.; Ponssen, H.H.; Janssens, E.N.W.; Fels, P.W. Ventricular fibrillation in hypercalcaemic crisis due to primary hyperparathyroidism. Neth. J. Med. 2004, 62, 94-96. [PubMed]

103. Wu, L.-S.; Wu, C.-T.; Hsu, L.-A.; Luqman, N.; Kuo, C.-T. Brugada-like electrocardiographic pattern and ventricular fibrillation in a patient with primary hyperparathyroidism. Europace 2007, 9, 172-174. [CrossRef]

104. Di Nunno, N.; Patanè, F.G.; Amico, F.; Asmundo, A.; Pomara, C. The Role of a Good Quality Autopsy in Pediatric Malpractice Claim: A Case Report of an Unexpected Death in an Undiagnosed Thymoma. Front. Pediatr. 2020, 8. [CrossRef]

105. Peterslund, P.; Elvander, C.F.; Hoffmann-Peterssen, J. Iatrogenic clinically cardiac arrest after administration of nitroglycerin. Ugeskr. Laeger 2019, 181, V01190015.

106. Wheeler, S.J.; Wheeler, D.W. Medication errors in anaesthesia and critical care. Anaesthesia 2005, 60, 257-273. [CrossRef]

107. Sicouri, S.; Antzelevitch, C. Mechanisms Underlying the Actions of Antidepressant and Antipsychotic Drugs That Cause Sudden Cardiac Arrest. Arrhythmia Electrophysiol. Rev. 2018, 7, 199-209. [CrossRef] [PubMed]

108. Sessa, F.; Salerno, M.; Di Mizio, G.; Bertozzi, G.; Messina, G.; Tomaiuolo, B.; Pisanelli, D.; Maglietta, F.; Ricci, P.; Pomara, C. Anabolic Androgenic Steroids: Searching New Molecular Biomarkers. Front. Pharmacol. 2018, 9, 9. [CrossRef] [PubMed]

109. Sessa, F.; Salerno, M.; Cipolloni, L.; Bertozzi, G.; Messina, G.; Di Mizio, G.; Asmundo, A.; Pomara, C. Anabolic-androgenic steroids and brain injury: miRNA evaluation in users compared to cocaine abusers and elderly people. Aging 2020, 12, 15314-15327. [CrossRef]

110. Fineschi, V.; Baroldi, G.; Monciotti, F.; Reattelli, L.P.; Turillazzi, E. Anabolic steroid abuse and cardiac sudden death: A pathologic study. Arch. Pathol. Lab. Med. 2001, 125, 253-255. [CrossRef]

111. Torrisi, M.; Pennisi, G.; Russo, I.; Amico, F.; Esposito, M.; Liberto, A.; Cocimano, G.; Salerno, M.; Rosi, G.L.; Di Nunno, N.; et al. Sudden Cardiac Death in Anabolic-Androgenic Steroid Users: A Literature Review. Medicina 2020, 56, 587. [CrossRef] [PubMed]

112. Turillazzi, E.; Bello, S.; Neri, M.; Pomara, C.; Riezzo, I.; Fineschi, V. Cardiovascular effects of cocaine: Cellular, ionic and molecular mechanisms. Curr. Med. Chem. 2012, 19, 5664-5676. [CrossRef]

113. Lingamfelter, D.C.; Knight, L.D. Sudden death from massive gastrointestinal hemorrhage associated with crack cocaine use: Case report and review of the literature. Am. J. Forensic Med. Pathol. 2010, 31, 98-99. [CrossRef]

114. Akinlonu, A.; Suri, R.; Yerragorla, P.; López, P.D.; Mene-Afejuku, T.O.; Ola, O.; Dumancas, C.; Chalabi, J.; Pekler, G.; Visco, F.; et al. Brugada Phenocopy Induced by Recreational Drug Use. Case Rep. Cardiol. 2018, 2018, 1-4. [CrossRef]

115. Stockholm, S.C.; Rosenblum, A.; Byrd, A.; Mery-Fernandez, E.; Bhandari, M. Cannabinoid-Induced Brugada Syndrome: A Case Report. Cureus 2020, 12, e8615. [CrossRef]

116. Boland, D.M.; Reidy, L.J.; Seither, J.M.; Radtke, J.M.; Lew, E.O. Forty-Three Fatalities Involving the Synthetic Cannabinoid, 5-Fluoro- ADB: Forensic Pathology and Toxicology Implications. J. Forensic Sci. 2020, 65, 170-182. [CrossRef]

117. Morentin, B.; Callado, L.F. Sudden cardiac death associated to substances of abuse and psychotropic drugs consumed by young people: A population study based on forensic autopsies. Drug Alcohol Depend. 2019, 201, 23-28. [CrossRef] [PubMed]

118. Neri, M.; Othman, S.M.; Cantatore, S.; De Carlo, D.; Pomara, C.; Riezzo, I.; Turillazzi, E.; Fineschi, V. Sudden infant death in an 8-month-old baby with dengue virus infection: Searching for virus in postmortem tissues by immunohistochemistry and Western blotting. Pediatric Infect. Dis. J. 2012, 31, 878-880. [CrossRef] [PubMed]

119. Sorkin, T.; Sheppard, M.N. Sudden unexplained death in alcohol misuse (SUDAM) patients have different characteristics to those who died from sudden arrhythmic death syndrome (SADS). Forensic Sci. Med. Pathol. 2017, 13, 278-283. [CrossRef]

120. Goldstein, R.D.; Blair, P.; Sens, M.A.; Shapiro-Mendoza, C.K.; Krous, H.F.; Rognum, T.O.; Moon, R.Y. Inconsistent classification of unexplained sudden deaths in infants and children hinders surveillance, prevention and research: Recommendations from The 3rd International Congress on Sudden Infant and Child Death. Forensic Sci. Med. Pathol. 2019, 15, 622-628. [CrossRef]

121. Bolliger, S.A.; Thali, M.J. Imaging and virtual autopsy: Looking back and forward. Philos. Trans. R. Soc. B Biol. Sci. 2015, 370, 20140253. [CrossRef] 
122. Ruder, T.; Thali, M.; Hatch, G. Essentials of forensic post-mortem MR imaging in adults. Br. J. Radiol. 2014, 87, 20130567. [CrossRef]

123. Bello, S.; Neri, M.; Grilli, G.; Pascale, N.; Pomara, C.; Riezzo, I.; Turillazzi, E.; Fineschi, V. Multi-phase post-mortem CTangiography (MPMCTA) is a very significant tool to explain cardiovascular pathologies. A sudden cardiac death case. Exp. Clin. Cardiol. 2014, 13, 855-865.

124. Kornegoor, R.; A A Brosens, L.; Roothaan, S.M.; Smits, A.J.J.; Vink, A. Digitalization of post-mortem coronary angiography. Histopathol. 2009, 55, 760-761. [CrossRef]

125. Grabherr, S.; Grimm, J.; Heinemann, A. Atlas of Postmortem Angiography; Springer: London, UK, 2016.

126. Michaud, K.; Grabherr, S.; Jackowski, C.; Bollmann, M.D.; Doenz, F.; Mangin, P. Postmortem imaging of sudden cardiac death. Int. J. Leg. Med. 2014, 128, 127-137. [CrossRef] [PubMed]

127. Michaud, K.; Genet, P.; Sabatasso, S.; Grabherr, S. Postmortem imaging as a complementary tool for the investigation of cardiac death. Forensic Sci. Res. 2019, 4, 211-222. [CrossRef]

128. Hueck, U.; Muggenthaler, H.; Hubig, M.; Heinrich, A.; Güttler, F.; Wagner, R.; Mall, G.; Teichgräber, U. Forensic postmortem computed tomography in suspected unnatural adult deaths. Eur. J. Radiol. 2020, 132, 109297. [CrossRef]

129. Barcelo, B.; Noce, V.; Gomila, I.; Martín, B.B. Building Bridges between Clinical and Forensic Toxicology Laboratories. Curr. Pharm. Biotechnol. 2018, 19, 99-112. [CrossRef]

130. Bjune, T.; Risgaard, B.; Kruckow, L.; Glinge, C.; Ingemann-Hansen, O.; Leth, P.M.; Linnet, K.; Banner, J.; Winkel, B.G.; TfeltHansen, J. Post-mortem toxicology in young sudden cardiac death victims: A nationwide cohort study. Europace 2017, 20, 614-621. [CrossRef]

131. Morentín, B.; Callado, L.F.; García-Hernández, S.; Bodegas, A.; Lucena, J. The role of toxic substances in sudden cardiac death. Span. J. Leg. Med. 2018, 44, 13-21. [CrossRef]

132. Mladěnka, P.; Applová, L.; Patočka, J.; Costa, V.M.; Remiao, F.; Pourová, J.; Mladěnka, A.; Karlíčková, J.; Jahodář, L.; Vopršalová, M.; et al. Comprehensive review of cardiovascular toxicity of drugs and related agents. Med. Res. Rev. 2018, 38, 1332-1403. [CrossRef]

133. Montisci, M.; El Mazloum, R.; Cecchetto, G.; Terranova, C.; Ferrara, S.D.; Thiene, G.; Basso, C. Anabolic androgenic steroids abuse and cardiac death in athletes: Morphological and toxicological findings in four fatal cases. Forensic Sci. Int. 2012, 217, e13-e18. [CrossRef]

134. Sessa, F.; Messina, G.; Russo, R.; Salerno, M.; Castracani, C.C.; Distefano, A.; Volti, G.L.; Calogero, A.E.; Cannarella, R.; Mongioi', L.M.; et al. Consequences on aging process and human wellness of generation of nitrogen and oxygen species during strenuous exercise. Aging Male 2020, 23, 14-22. [CrossRef]

135. Francavilla, C.V.; Sessa, F.; Salerno, M.; Albano, G.D.; Villano, I.; Messina, G.; Triolo, F.; Todaro, L.; Ruberto, M.; Marsala, G.; et al. Influence of Football on Physiological Cardiac Indexes in Professional and Young Athletes. Front. Physiol. 2018, 9, 9. [CrossRef]

136. Giudicessi, J.R.; Ackerman, M.J. Determinants of incomplete penetrance and variable expressivity in heritable cardiac arrhythmia syndromes. Transl. Res. 2013, 161, 1-14. [CrossRef]

137. Miles, C.J.; Behr, E.R. The role of genetic testing in unexplained sudden death. Transl. Res. 2016, 168, 59-73. [CrossRef]

138. Wilhelm, M.; Bolliger, S.A.; Bartsch, C.; Fokstuen, S.; Gräni, C.; Martos, V.; Medeiros Domingo, A.; Osculati, A.; Rieubland, C.; Sabatasso, S.; et al. Sudden cardiac death in forensic medicine-Swiss recommendations for a multidisciplinary approach. Swiss Med. Wkly. 2015, 145, 14129. [CrossRef]

139. Tester, D.J.; Medeiros-Domingo, A.; Will, M.L.; Ackerman, M.J. Unexplained Drownings and the Cardiac Channelopathies: A Molecular Autopsy Series. Mayo Clin. Proc. 2011, 86, 941-947. [CrossRef]

140. Skinner, J.R.; Crawford, J.; Smith, W.; Aitken, A.; Heaven, D.; Evans, C.-A.; Hayes, I.; Neas, K.R.; Stables, S.; Koelmeyer, T.; et al. Prospective, population-based long QT molecular autopsy study of postmortem negative sudden death in 1 to 40 year olds. Hear. Rhythm. 2011, 8, 412-419. [CrossRef]

141. Turillazzi, E.; La Rocca, G.; Anzalone, R.; Corrao, S.; Neri, M.; Pomara, C.; Riezzo, I.; Karch, S.B.; Fineschi, V. Heterozygous nonsense SCN5A mutation W822X explains a simultaneous sudden infant death syndrome. Virchows Arch. 2008, 453, 209-216. [CrossRef]

142. Pomara, C.; D’Errico, S.; Riezzo, I.; De Cillis, G.P.; Fineschi, V. Sudden cardiac death in a child affected by Prader-Willi syndrome. Int. J. Leg. Med. 2005, 119, 153-157. [CrossRef]

143. Bafunno, V.; Bury, L.; Tiscia, G.L.; Fierro, T.; Favuzzi, G.; Caliandro, R.; Sessa, F.; Grandone, E.; Margaglione, M.; Gresele, P. A novel congenital dysprothrombinemia leading to defective prothrombin maturation. Thromb. Res. 2014, 134, 1135-1141. [CrossRef]

144. Santacroce, R.; Santoro, R.; Sessa, F.; Iannaccaro, P.; Sarno, M.; Longo, V.; Gallone, A.; Vecchione, G.; Muleo, G.; Margaglione, M. Screening of mutations of hemophilia A in 40 Italian patients: A novel G-to-A mutation in intron 10 of the F8 gene as a putative cause of mild hemophilia a in southern Italy. Blood Coagul. Fibrinolysis 2008, 19, 197-202. [CrossRef]

145. Marey, I.; Fressart, V.; Rambaud, C.; Fornes, P.; Martin, L.; Grotto, S.; Alembik, Y.; Gorka, H.; Millat, G.; Gandjbakhch, E.; et al. Clinical impact of post-mortem genetic testing in cardiac death and cardiomyopathy. Open Med. 2020, 15, 435-446. [CrossRef]

146. Brion, M.; Quintela, I.; Sobrino, B.; Torres, M.; Allegue, C.; Carracedo, A. New technologies in the genetic approach to sudden cardiac death in the young. Forensic Sci. Int. 2010, 203, 15-24. [CrossRef] 
147. Stattin, E.-L.; Westin, I.M.; Cederquist, K.; Jonasson, J.; Jonsson, B.-A.; Mörner, S.; Norberg, A.; Krantz, P.; Wisten, A. Genetic screening in sudden cardiac death in the young can save future lives. Int. J. Leg. Med. 2016, 130, 59-66. [CrossRef] [PubMed]

148. Khera, A.V.; Mason-Suares, H.; Brockman, D.; Wang, M.; VanDenburgh, M.J.; Senol-Cosar, O.; Patterson, C.; Newton-Cheh, C.; Zekavat, S.M.; Pester, J.; et al. Rare Genetic Variants Associated with Sudden Cardiac Death in Adults. J. Am. Coll. Cardiol. 2019, 74, 2623-2634. [CrossRef] [PubMed]

149. Morini, E.; Sangiuolo, F.; Caporossi, D.; Novelli, G.; Amati, F. Application of Next Generation Sequencing for personalized medicine for sudden cardiac death (SCD). Front. Genet. 2015, 6, 55. [CrossRef]

150. Carturan, E.; Tester, D.J.; Brost, B.C.; Basso, C.; Thiene, G.; Ackerman, M.J. Postmortem genetic testing for conventional autopsynegative sudden unexplained death: An evaluation of different DNA extraction protocols and the feasibility of mutational analysis from archival paraffin-embedded heart tissue. Am. J. Clin. Pathol. 2008, 129, 391-397. [CrossRef] [PubMed]

151. Basso, C.; Calabrese, F.; Angelini, A.; Carturan, E.; Thiene, G. Classification and histological, immunohistochemical, and molecular diagnosis of inflammatory myocardial disease. Heart Fail. Rev. 2012, 18, 673-681. [CrossRef]

152. Boczek, N.J.; Tester, D.J.; Ackerman, M.J. The molecular autopsy: An indispensable step following sudden cardiac death in the young? Herzschrittmachertherapie Elektrophysiologie 2012, 23, 167-173. [CrossRef]

153. Basso, C.; Carturan, E.; Pilichou, K.; Rizzo, S.; Corrado, D.; Thiene, G. Sudden cardiac death with normal heart: Molecular autopsy. Cardiovasc. Pathol. 2010, 19, 321-325. [CrossRef] [PubMed]

154. Neri, M.; Frati, A.; Turillazzi, E.; Cantatore, S.; Cipolloni, L.; Di Paolo, M.; Frati, P.; La Russa, R.; Maiese, A.; Scopetti, M.; et al. Immunohistochemical Evaluation of Aquaporin-4 and its Correlation with CD68, IBA-1, HIF-1 $\alpha$, GFAP, and CD15 Expressions in Fatal Traumatic Brain Injury. Int. J. Mol. Sci. 2018, 19, 3544. [CrossRef]

155. Dunn, K.E.; Caleshu, C.; Cirino, A.L.; Ho, C.Y.; Ashley, E.A. A clinical approach to inherited hypertrophy: The use of family history in diagnosis, risk assessment, and management. Circ. Cardiovasc. Genet. 2013, 6, 118-131. [CrossRef]

156. D’Ovidio, C.; Carnevale, A.; Grassi, V.M.; Rosato, E.; Del Olmo, B.; Coll, M.; Campuzano, O.; Iglesias, A.; Brugada, R.; Oliva, A. Sudden death due to catecholaminergic polymorphic ventricular tachycardia following negative stress-test outcome: Genetics and clinical implications. Forensic Sci. Med. Pathol. 2017, 13, 217-225. [CrossRef]

157. Cunningham, K.S. The Promise of Molecular Autopsy in Forensic Pathology Practice. Acad. Forensic Pathol. 2017, 7, 551-566. [CrossRef] [PubMed]

158. Lin, Y.; Williams, N.; Wang, D.; Coetzee, W.; Zhou, B.; Eng, L.S.; Um, S.Y.; Bao, R.; Devinsky, O.; McDonald, T.V.; et al. Applying High-Resolution Variant Classification to Cardiac Arrhythmogenic Gene Testing in a Demographically Diverse Cohort of Sudden Unexplained Deaths. Circ. Cardiovasc. Genet. 2017, 10. [CrossRef] [PubMed]

159. Paratz, E.D.; Rowsell, L.; Zentner, D.; Parsons, S.; Morgan, N.; Thompson, T.; James, P.; Pflaumer, A.; Semsarian, C.; Smith, K.; et al. Cardiac arrest and sudden cardiac death registries: A systematic review of global coverage. Open Heart 2020, 7, e001195. [CrossRef] [PubMed] 